\title{
Control of Blue Mold of Apples by Preharvest Application of Candida sake Grown in Media with Different Water Activity
}

\author{
N. Teixidó, I. Viñas, J. Usall, and N. Magan
}

First, second, and third authors: Postharvest Unit, CeRTA, Centre UdL-IRTA, 177 Rovira Roure Avenue, 25198, Lleida, Spain; and fourth author: Applied Mycology Group, Biotechnology Centre, Cranfield University, Cranfield, Bedford MK43 0AL, United Kingdom. Accepted for publication 29 May 1998.

\begin{abstract}
Teixidó, N., Viñas, I., Usall, J., and Magan, N. 1998. Control of blue mold of apples by preharvest application of Candida sake grown in media with different water activity. Phytopathology 88:960-964.

Unmodified and low water activity $\left(a_{\mathrm{w}}\right)$-tolerant cells of Candida sake CPA-1 applied before harvest were compared for ability to control blue mold of apples ('Golden Delicious') caused by Penicillium expansum under commercial storage conditions. The population dynamics of strain CPA-1 on apples were studied in the orchard and during storage following application of $3 \times 10^{6} \mathrm{CFU} / \mathrm{ml}$ of each treatment 2 days prior to harvest. In the field, the population size of the unmodified treatment remained relatively unchanged, while the population size of the low- $a_{\mathrm{w}}-$ modified CPA- 1 cells
\end{abstract}

ABSTRACT increased. During cold storage, the populations in both treatments increased from $10^{3}$ to $10^{5} \mathrm{CFU} / \mathrm{g}$ of apple after 30 days, and then declined to about $2.5 \times 10^{4} \mathrm{CFU} / \mathrm{g}$ of apple. In laboratory studies, the low- $a_{\mathrm{w}}-$ tolerant cells provided significantly better disease control as compared with the unmodified cells and reduced the number of infected wounds and lesion size by 75 and $90 \%$, respectively, as compared with the nontreated controls. After 4 months in cold storage, both unmodified and low- $a_{\mathrm{w}}-$ tolerant cells of $C$. sake were equally effective against $P$. expansum on apple ( $>50 \%$ reduction in size of infected wounds).

Additional keywords: compatible solutes, ecophysiology, growth, postharvest diseases, sugars, sugar alcohols.
The development of resistance in fungal pathogens to fungicides $(2,6,33,36,42,44)$ and the growing public concern over the health and environmental hazards associated with high levels of pesticide use in fruit orchards $(25,47)$ have resulted in a significant interest in the development of alternative nonchemical methods of disease control. Biological control using microbial antagonists has emerged as one of the most promising alternatives, either alone or as part of an integrated control strategy to reduce pesticide inputs. Many antagonists of fungal pathogens of fruits have been reported $(15,16$, $29,30,34,45)$. Biocontrol of postharvest pathogens has been very successful, as indicated by a number of commercial products on the market (18) including Aspire (Candida oleophila strain 182; Ecogen Inc., Langhorne, PA) and Bio-Save 10 and 11 (Pseudomonas syringae strains ESC10 and ESC 11; EcoScience Corp., Worcester, MA). Studies in Spain have demonstrated that Candida sake (Saito and Ota) van Uden and Buckley strain CPA-1 is an effective antagonist of the major postharvest pathogens of pome fruits including Penicillium expansum Link and Botrytis cinerea Pers.:Fr. $(39,43)$.

Infection of fruit by postharvest pathogens often occurs in the field prior to harvest $(3,32)$; therefore, it would be advantageous to apply antagonists before harvest, which would reduce initial infection and then remain active and suppress the pathogens in storage $(8,9)$. European regulations of integrated pest management do not allow postharvest treatment of apples, and the European Parliament has voted in favor of a total ban on postharvest pesticide treatments of fruits and vegetables with chemicals as soon as this practice becomes feasible (31). Recently, Leibinger et al. (21) used mixtures of yeasts and bacteria for control of apple postharvest diseases and obtained a level of control of $P$. expansum and $B$. cinerea that was

Corresponding author: N. Teixidó;

E-mail address: TMP5IE12@LLEIDA.IRTA.ES

Publication no. P-1998-0709-01R

(C) 1998 The American Phytopathological Society similar to that obtained with a fungicide. For this approach to be successful, inocula need tolerance to environmental stresses, especially of high temperature, low water activity $\left(a_{\mathrm{w}}\right)$, low nutrient conditions, and UV light, for effective establishment and disease control (5). However, few studies have tried to improve the competence, survival, and activity of such biocontrol agents in the field for improving subsequent disease control $(7,46)$.

Recent physiological studies with $C$. sake CPA-1 demonstrated that growth conditions can be modified so that specific endogenous compounds such as sugar alcohols and trehalose accumulate in cells, resulting in improved viability over a wider range of relative humidities with retained biocontrol efficacy $(37,38)$. Accumulation of low- (glycerol and erythritol) and high- (arabitol and mannitol) molecular-weight sugar alcohols occurs in many fungi grown under conditions of environmental stress (1, $10,14,17,40)$. Intracellular accumulation of these polyols reduces cytoplasmatic $a_{\mathrm{w}}$ and enables enzymes to remain active during periods of water stress (4). Conidia of entomopathogenic biocontrol fungi with elevated concentrations of polyols (erythritol and glycerol) tolerated lower water activities and were more pathogenic than unmodified conidia $(11,12)$. Physiologically manipulated inocula of the biocontrol agent Epicoccum nigrum containing high concentrations of glycerol and erythritol provided better field control of Monilinia laxa of peaches than unmodified inocula (28). Some studies have also suggested that the disaccharide trehalose may also be important as it enhances desiccation tolerance and increases viability and germination of fungi at reduced $a_{\mathrm{w}}(13,26,41)$.

The objectives of this study were to compare the establishment and temporal population dynamics of one unmodified and two physiologically modified low- $a_{\mathrm{w}}$-tolerant inocula of $C$. sake CPA-1 on apple surfaces in the orchard and during cold storage; and to compare the biocontrol activity of unmodified and low- $a_{\mathrm{w}}-$ tolerant treatments of the yeast applied in the field to 'Golden Delicious' apples for control of blue mold caused by $P$. expansum during cold storage. 


\section{MATERIALS AND METHODS}

Antagonist strains and pathogen. $C$. sake strain CPA-1 was obtained from the UdL-IRTA Centre, Catalonia, Spain. It originally was isolated from the surface of an apple (cv. Golden Delicious) and previously was shown to have antagonistic activity against $P$. expansum, B. cinerea, and Rhizopus nigricans on pome fruits (39, 43). Stock cultures were stored at $5^{\circ} \mathrm{C}$ and were subcultured on nutrient yeast dextrose agar (NYDA; $8 \mathrm{~g}$ of nutrient broth, $5 \mathrm{~g}$ of yeast extract, $10 \mathrm{~g}$ of dextrose, $20 \mathrm{~g}$ of agar, and 1,000 $\mathrm{ml}$ of water). The pathogen $P$. expansum (CMP-1) was isolated from decayed apples after several months in storage and maintained on potato dextrose agar (PDA; $200 \mathrm{ml}$ of extract from boiled potatoes, $20 \mathrm{~g}$ of dextrose, $20 \mathrm{~g}$ of agar, and $800 \mathrm{ml}$ of water). To maintain virulence, it was periodically grown on apple and reisolated. This is the most virulent isolate in the University of Lleida-IRTA collection and was used in all experiments. A conidial suspension was prepared by adding $10 \mathrm{ml}$ of sterile water over the surface of 10-dayold cultures grown on PDA and agitating the surface with a sterile glass rod. The cells were counted in a haemocytometer and diluted to give a concentration of $10^{4} \mathrm{CFU} / \mathrm{ml}$ for use in disease control experiments.

Fruits and orchards. The apple cultivar Golden Delicious was used in all experiments. Fruit trees (8 years old) and fruit (freshly harvested, 1996) were from a commercial orchard in Aitona (Lleida), Catalonia, Spain, and were grown under standard cultural practices.

Growth media. An unmodified nutrient yeast dextrose broth (NYDB; $0.995 a_{\mathrm{w}}$ ) was used as the basal medium. Low- $a_{\mathrm{w}}-$ tolerant modified inocula were cultured in NYDB amended with either (i) glucose (398 g/liter) to modify the medium to $0.96 a_{\mathrm{w}}$ and diluted by $50 \%$ with water prior to $a_{\mathrm{w}}$ modification (NYDB50+GLU) or (ii) glycerol (184 g/liter) to modify the medium to $0.96 a_{\mathrm{w}}$ and diluted by $75 \%$ prior to $a_{\mathrm{w}}$ modification (NYDB25+GLY) (37). Cultures were incubated for $48 \mathrm{~h}$ at $25^{\circ} \mathrm{C}$ on an orbital incubator (Gallenkamp, Leicester, United Kingdom) at $150 \mathrm{rpm}$. The $a_{\mathrm{w}}$ of all media was determined with a Novasina Humidat IC II (Novasina AG, Zurich, Switzerland).

In previous studies, inocula of $C$. sake grown on these media contained elevated amounts of glycerol and trehalose and were found to be the most viable cells in in vitro assays at different $a_{\mathrm{w}}$ levels (37).

Recovery of $\boldsymbol{C}$. sake from the surfaces of apple. Treated apples were weighed and aseptically peeled. The peels and wounded areas were shaken in $200 \mathrm{ml}$ of sterile phosphate buffer ( $\mathrm{pH} \mathrm{7.0)}$ on a rotary shaker for $20 \mathrm{~min}$ at $150 \mathrm{rpm}$, and then sonicated for $10 \mathrm{~min}$ in an ultrasound bath (Selecta; Abrera, Barcelona, Spain) to improve detachment of microorganisms from the apple surface. Serial dilutions of the washings were made and plated on NYDA amended with streptomycin sulfate $(0.5 \mathrm{~g} /$ liter $)$ to inhibit bacteria. Colonies were counted after incubation for $48 \mathrm{~h}$ at $25^{\circ} \mathrm{C}$ in the dark. Colonies of $C$. sake CPA-1 were easily identified, because they have a distinct morphology. The identity of random colonies of $C$. sake CPA-1 was confirmed by using an identification system for yeasts (ID32C; Biomérieux S.A., Marcy-l'Etoile, France). Population sizes were expressed as CFU/g fresh weight of fruit.

Growth of modified and unmodified $C$. sake on the surface of apples. Cells of $C$. sake were grown in NYDB, NYDB50+GLU, and NYDB25+GLY and were applied at doses of $5 \times 10^{5}, 10^{6}$, and $10^{7} \mathrm{CFU} / \mathrm{ml}$ to ripe apples in the orchard. The treatments were applied onto attached apple fruits with a hand gun (Maruyama MS 056; Maruyama, Tokyo) operating at a pressure of 10 atmospheres. Each fruit had four wounds, made with a nail $(1 \mathrm{~mm}$ diameter) pressed to a depth of $1 \mathrm{~mm}$, equidistant from each other in the equatorial plane of the apple. Two apples from one tree constituted a replicate, and there were four replicate trees per treatment. Treatments were arranged in a randomized complete block design, with guard trees used to separate the treatments. Samples were harvested immediately after treatment $(0 \mathrm{~h})$ and $48 \mathrm{~h}$ later. The experiment was carried out twice in August 1996 on different trees. Apple surfaces were washed as described above, and washings were serially diluted and plated onto NYDA medium to determine population sizes of $C$. sake.

The experiment was a $3 \times 2 \times 3$ factorial; main effects and interactions were analyzed for significance by analysis of variance (ANOVA) with SAS software (version 6.03; SAS Institute, Cary, NC). This enabled the statistical significance of one-, two-, and three-way interactions to be examined. Statistical significance was judged at $P=0.0001$. The least significant difference (LSD) test was used for means separation.

In another study, the modified and unmodified cells of $C$. sake were prepared as described above, and suspensions of $3 \times 10^{6} \mathrm{CFU} /$ $\mathrm{ml}$ were placed in 1,000-ml beakers. Wounded apples were dipped into the antagonist suspension for $30 \mathrm{~s}$ just after wounding. Apples were harvested when dry, and one apple from each replicate of each treatment was taken to the laboratory to sample populations of $C$. sake as described above. Each treatment consisted of four replicate trees, with a total of 10 apples per replicate being artificially wounded as detailed above. Trees were sampled at 0,24 , and $48 \mathrm{~h}$ after inoculation. After $48 \mathrm{~h}$, the remaining treated apples were harvested and placed in cold storage $\left(1{ }^{\circ} \mathrm{C}\right.$ and $\left.21 \% \mathrm{O}_{2}\right)$. Population sizes of $C$. sake cells on apple surfaces were determined after $1,7,15,30,60$, and 120 days in cold storage as described above. The experiment was repeated twice.

Data of C. sake populations (CFU/g fresh weight) were transformed to logarithms to improve homogeneity of variances (27), and ANOVA for each sample date was conducted with SAS software. Statistical significance was judged at $P=0.001$ and the Dunnet procedure used for means separation.

Suppression of blue mold during cold storage by $C$. sake applied to apples in the orchard. Suspensions of $C$. sake (one unmodified and two $a_{\mathrm{w}}$-tolerant treatments) were prepared to give concentrations of $10^{7} \mathrm{CFU} / \mathrm{ml}$. Each treatment consisted of four replicates and were arranged in a random complete block design. Each replicate consisted of three trees (70 ripe apples per replication). In all cases, a guard row of trees was used to separate the treatments. Apples were wounded 2 days before harvest as described above, and treatments were applied using a hand gun operated at 10 atmospheres of pressure. Application apples were harvested 2 days after the treatment and placed in storage boxes according to replicate and treatment. Before cold storage, apples were sprayed for $30 \mathrm{~s}$ with a suspension of $P$. expansum at a concentration of $1 \times 10^{4}$ conidia per ml. Once dried, apples were stored at $1{ }^{\circ} \mathrm{C}$ and $21 \% \mathrm{O}_{2}$, which is typical of commercial cold storage. There was a total of 70 fruits per replicate and four replicates per treatment. The number of infected wounds and the lesion diameters $(\mathrm{mm})$ were measured 2 and 4 months after cold storage. The experiment was carried out twice. ANOVA from SAS was performed on disease incidence and on severity data $(P=0.0001)$, and an LSD test was used for means separation.

Suppression of blue mold by modified and unmodified $\boldsymbol{C}$. sake in laboratory conditions. Apples from the same orchard were used in the laboratory for short-term disease control assays and two concentrations of $C$. sake were tested $\left(7.5 \times 10^{5}\right.$ and $1.6 \times 10^{6}$ $\mathrm{CFU} / \mathrm{ml}$ ). Surface-sterilized apples were wounded at the stem (top) and calyx (bottom), with each wound being $3 \times 3 \mathrm{~mm}$ in area and $3 \mathrm{~mm}$ deep. Aliquots $(25 \mu \mathrm{l})$ of each treatment (unmodified and low- $a_{\mathrm{w}}$-tolerant treatments) were applied to each wound, and 20 $\mu \mathrm{l}$ of an aqueous suspension of $P$. expansum $\left(1 \times 10^{4}\right.$ conidia per $\left.\mathrm{ml}\right)$ was added. Each treatment was replicated four times with three apples per replicate, and the experiment was repeated twice. Treated apples were incubated at $25^{\circ} \mathrm{C}$ and $75 \%$ relative humidity for 7 days, after which the percentage of infected wounds (incidence) and lesion diameters (severity) caused by $P$. expansum were determined.

The experiment was a $3 \times 3$ factorial, and the main effects and interactions were analyzed by ANOVA with SAS software. This enabled the statistical significance of one- and two-way inter- 
actions to be examined. Statistical significance was judged at the level $P=0.0001$, and the LSD test was used for means separation.

\section{RESULTS}

Population sizes of $\boldsymbol{C}$. sake sprayed onto apples in the field. Statistical analysis of the population sizes of $C$. sake after 0 and $48 \mathrm{~h}$ on apples showed that single treatments (treatment, inoculum concentration, and sample time) and the two-way interaction of treatment $\times$ time were statistically significant. There was no significant interaction between treatment $\times$ concentration; therefore, the results for the different concentrations were pooled (Fig. 1).

Immediately after application $(0 \mathrm{~h})$, the population size of unmodified $C$. sake was higher than those of the two low- $a_{\mathrm{w}}-$ tolerant $C$. sake. However, after $48 \mathrm{~h}$, the population size of $C$. sake from glucose-amended media was greater than the population size of $C$. sake from glycerol-amended media. The population size of unmodified $C$. sake did not increase over this period and was significantly less than the populations of both modified treatments $(P=$ 0.0001).

Population dynamics of $C$. sake on apples dipped into inoculum. The temporal changes in the populations of $C$. sake of each treatment in the field on 'Golden Delicious' apples are shown in Figure 2A. Initially, the population size of the unmodified inoculum was significantly $(P=0.001)$ greater on apples in the orchard than populations of the two $a_{\mathrm{w}}$-tolerant treatments. However, after 1 day, the population sizes of the unmodified treatment decreased slightly, while those of the two low- $a_{\mathrm{w}}-$ tolerant treatments increased. After 2 days, the number of modified $a_{\mathrm{w}}$-tolerant $C$. sake cells isolated from the apple surface was significantly $(P=0.001)$ greater than that of the unmodified treatment.

In cold storage, the population sizes of all three treatments were similar for about 15 days (Fig. 2B). At day 30, the population of the glucose-modified $a_{\mathrm{w}}$-tolerant treatment was lower than that of either the unmodified treatment or the glycerol-modified $a_{\mathrm{w}}$-tolerant treatment, which had the highest $C$. sake populations. At the end of the 4-month period in cold storage, all treatments had similar population sizes.

Suppression of blue mold during storage by $C$. sake sprayed onto apples in the field. Blue mold was significantly $(P=0.0001)$ greater on control apples (treated with $P$. expansum only) as com-

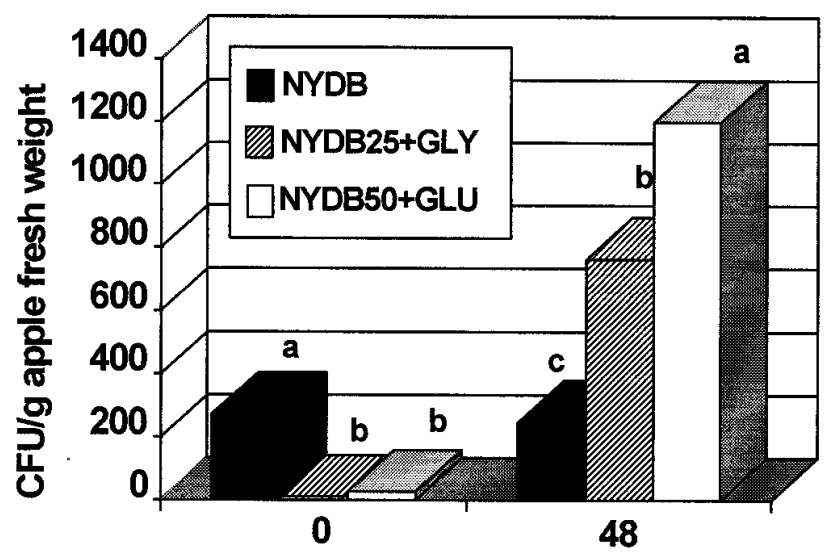

\section{Time after $C$. sake treatment (h)}

Fig. 1. Populations of Candida sake CPA-1 on the surface of apples at 0 and $48 \mathrm{~h}$ after the application of unmodified cells of $C$. sake grown on nutrient yeast dextrose broth (NYDB) and two low water activity $\left(a_{\mathrm{w}}\right)$-tolerant cells grown on media amended with glucose (NYDB50+GLU) or glycerol (NYDB25+GLY). Within times of sampling, columns with the same letter are not significantly different $(P=0.0001)$ according to the least significant difference test. Maximum temperature reached during the field assay was $37^{\circ} \mathrm{C}$. pared with apples sprayed with the three different $C$. sake treatments (Fig. 3). This was demonstrated by measurements of lesion diameter (severity) and the percentage of infected wounds (incidence). No differences were observed among the three $C$. sake treatments.

Suppression of blue mold by $\boldsymbol{C}$. sake in laboratory conditions. In the laboratory experiments, all $C$. sake treatments significantly inhibited development of blue mold (Fig. 4). The absence of significant interaction among treatments and concentrations allowed analyses of both concentrations of each treatment together. Severity and incidence of the disease were significantly lower in apples inoculated with low- $a_{\mathrm{w}}-$ tolerant glucose and glycerol cells of $C$. sake. Suppression of lesion diameter was greater than $90 \%$ and the percentage of infected wounds was greater than $75 \%$ with both concentrations of the $a_{\mathrm{w}}$-tolerant treatments. For the lower dose of $C$. sake $\left(7.5 \times 10^{5} \mathrm{CFU} / \mathrm{ml}\right)$, disease suppression by the unmodified treatment was less than that by the modified treatments (NYDB50+GLU and NYDB25+GLY). The unmodified treatment reduced lesion diameter and percentage of infected wounds by 72 and $49 \%$, respectively, whereas the treatment modified with glucose reduced these parameters by 90 and $78 \%$, respectively. For the higher dose $\left(1.6 \times 10^{6} \mathrm{CFU} / \mathrm{ml}\right)$, all treatments reduced lesion diameter and percentage of infected wounds at least 94 and $89 \%$, respectively.
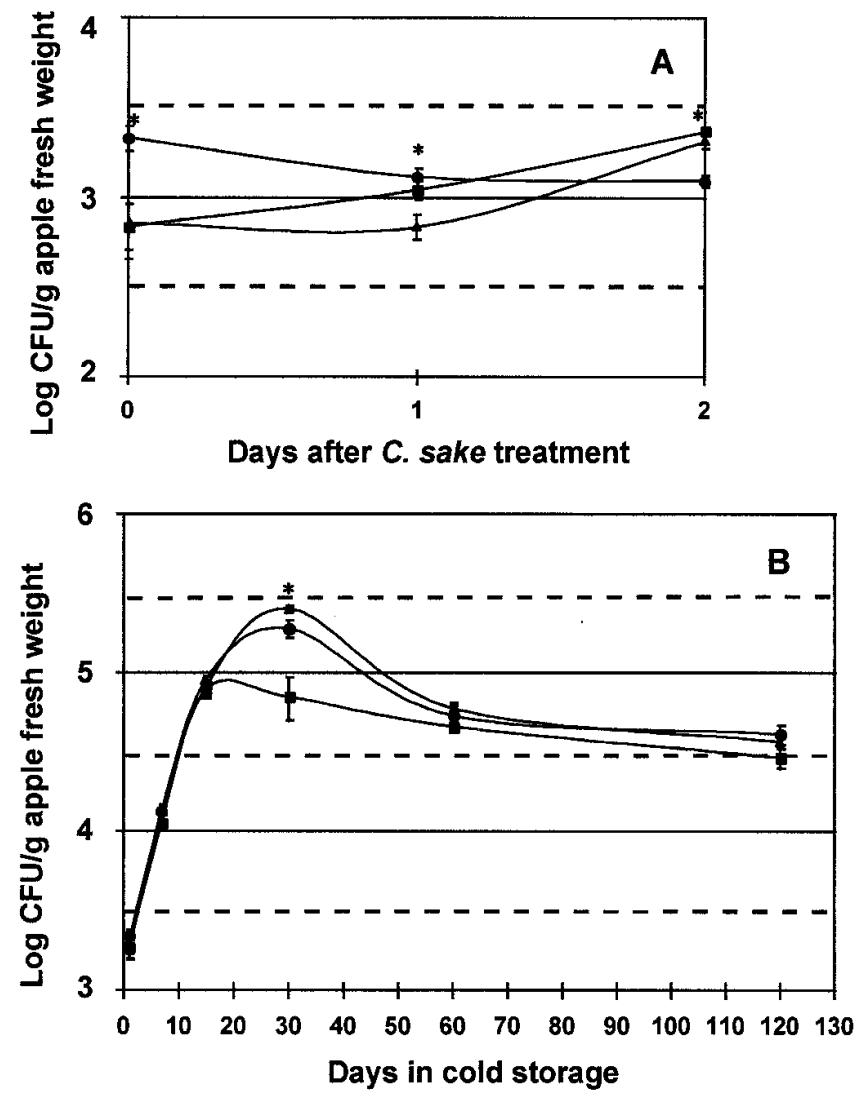

Fig. 2. Population dynamics of Candida sake CPA-1 grown in different media on 'Golden Delicious' apple surfaces A, during 2 days in the field and B, during cold storage. Antagonist suspensions were applied to wounded apples in the field 2 days prior to harvesting. Fruit samples were removed at various times to isolate antagonists from the surface. Treatments consisted of C. sake grown in unmodified nutrient yeast dextrose broth (NYDB), in NYDB diluted by $50 \%$ with water and amended with glucose to modify water activity $\left(a_{\mathrm{w}}\right)$ to 0.96 (NYDB50+GLU), and in NYDB diluted by $75 \%$ with water and amended with glycerol to modify $a_{\mathrm{w}}$ to 0.96 (NYDB25+GLY). NYDB; $\boldsymbol{\square}=$ NYDB50+GLU; and $\boldsymbol{\Delta}=$ NYDB25+GLY. Statistical differences $(P=0.001)$ between unmodified and modified cells according to the Dunnet procedure are shown with asterisks. Points represent the means of four replicates and the vertical bars are standard errors. Maximum temperature reached during the field assay was $34^{\circ} \mathrm{C}$. 


\section{DISCUSSION}

This study is the first detailed investigation on the comparison of unmodified and physiologically modified $a_{\mathrm{w}}$-tolerant inocula applied in the orchard to enhance establishment of antagonists on apple surfaces for postharvest disease control. We have demonstrated that it is possible to apply biocontrol agents in the orchard prior to harvest and, thus, have them established on apples in order to provide postharvest control of wound pathogen. Both unmodified and low$a_{\mathrm{w}}$-tolerant treatment populations survived when sprayed in the field, subsequently increased their population size for up to 30 days during storage, and controlled blue mold. The initial survival in populations of all three inocula in the preliminary experiment was lower than in the subsequent full-field trial, although the final populations achieved prior to harvest were similar.

Previously, Teixidó et al. $(37,38)$ demonstrated that it was possible to significantly alter the endogenous sugar alcohols and sugars present in the cells of $C$. sake. Cells grown under water stress with either glucose or glycerol contained a mixture of the sugar alcohols glycerol, arabitol, and the disaccharide trehalose, which appeared to be important in improving viability of the yeast cells and tolerance to lowered $a_{\mathrm{w}}$ stress. The polyols are known to be important solutes that accumulate in cells, enabling cell functioning under environmental stress, particularly lowered $a_{\mathrm{w}}$, and the trehalose is critical for preventing desiccation and has a role as a cryoprotectant (41). Previously, fungal biocontrol agents of pests that contained elevated concentrations of the low-molecular-weight polyols (glycerol and erythritol) had significantly improved germination and biocontrol activity against insect larvae $(11,12)$. Similarly, this study also has shown that the two $a_{\mathrm{w}}$-tolerant inocula suppressed blue mold significantly better than the unmodified inoculum, especially at lower concentrations in laboratory studies. The potential for using lower inoculum doses for achieving control is very important from an economic point of view and also in relation to retaining viability and inoculum quality during formulation.

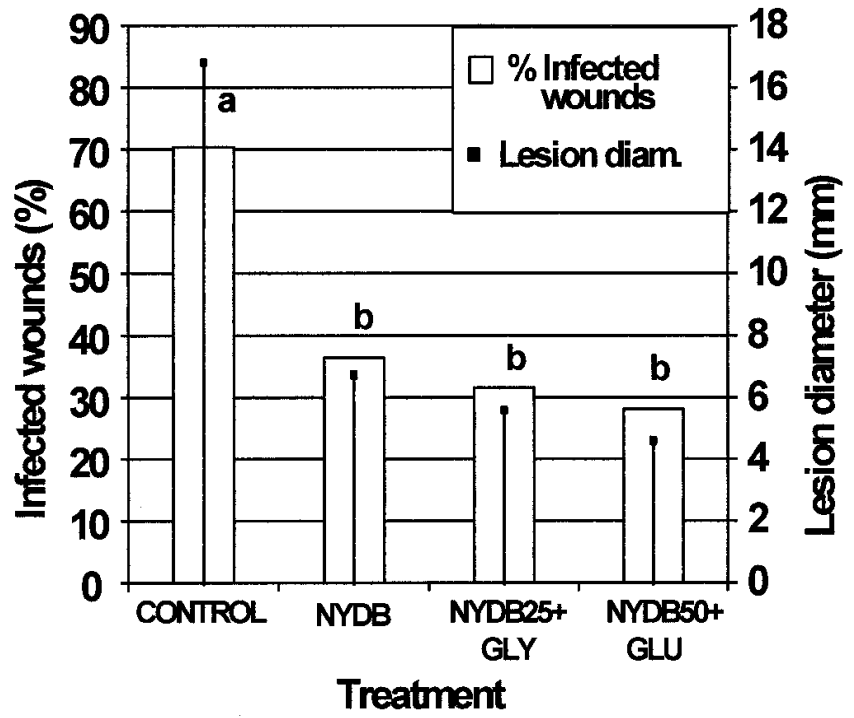

Fig. 3. Suppression of blue mold of 'Golden Delicious' apples by Candida sake CPA-1 grown in different media. Fruit were wounded in the field, and suspensions of the antagonist $\left(10^{7} \mathrm{CFU} / \mathrm{ml}\right)$ were sprayed onto the apples 2 days prior to harvest. The control was not treated. After harvest, all fruit were sprayed with an aqueous suspension of Penicillium expansum at $10^{4}$ conidia per ml and kept in cold storage for 4 months. Columns and lines with the same letter are not significantly different according to least significant difference test $(P=$ 0.0001). The letters apply to both percentage of infected wounds and lesion diameter. Treatments consisted of $C$. sake grown in unmodified nutrient yeast dextrose broth (NYDB), in NYDB diluted by $50 \%$ with water and amended with glucose to modify water activity $\left(a_{\mathrm{w}}\right)$ to 0.96 (NYDB50+GLU), and in NYDB diluted by $75 \%$ with water and amended with glycerol to modify $a_{\mathrm{w}}$ to 0.96 (NYDB25+GLY).
The only other study on preharvest application of biocontrol treatments for postharvest control of apple diseases, done by Leibinger et al. (21), involved the use of mixtures of strains of Aureobasidium pullulans and Rhodotorula glutinis, and Bacillus subtilis and A. pullulans. By applying these treatments three times before harvest, they increased populations of the biocontrol agents on the apple surface prior to harvest. However, during cold storage, population sizes rapidly decreased. With a mixture of $A$. pullulans at $10^{6}$ and $B$. subtilis at $10^{8}$ cells per $\mathrm{ml}$, they obtained control of $P$. expansum and $B$. cinerea similar to that achieved with a fungicide. Other studies have concentrated on foliar disease control of $B$. cinerea on various crops with preharvest application of Trichoderma harzianum and Ulocladium atrum $(9,19,20)$. They found, respectively, that relative humidity and periods of leaf wetness had a significant effect on establishment of the biocontrol agents, although the use of low$a_{\mathrm{w}}$-tolerant strains was not investigated in these studies. McKenzie et al. (24) found that unformulated pure conidial suspensions of $T$. harzianum did not survive effectively under field conditions. However, Smilanick et al. (35) have suggested that early application of the biocontrol agent in the field may enable early colonization and give protection against latent infections. In the current study, it is noteworthy that, 1 day after application in the field, the populations of the unmodified yeast decreased rapidly. However, although the $a_{\mathrm{w}}$-tolerant treatments developed more slowly over the 2 to 3 days prior to harvest, their populations increased markedly, particularly that of the glycerol-modified treatment.

In these experiments, it was also observed that unmodified yeast cells initially adhered better to the apple surface than the two low$a_{\mathrm{w}}$-tolerant treatments. Little is known about the characteristics of the polysaccharide matrix produced by yeasts such as $C$. sake. However, previous studies with such polysaccharide matrices of spores of other fungi suggest that they may have a number of important ecological properties including protection against temperature extremes, desiccation, and short-wave radiation $(22,23)$. It is possible that the energy requirements for the production of high concentrations of endogenous reserves such as polyols and trehalose $(37,38)$ could result in a modification of the amount or characteristics of

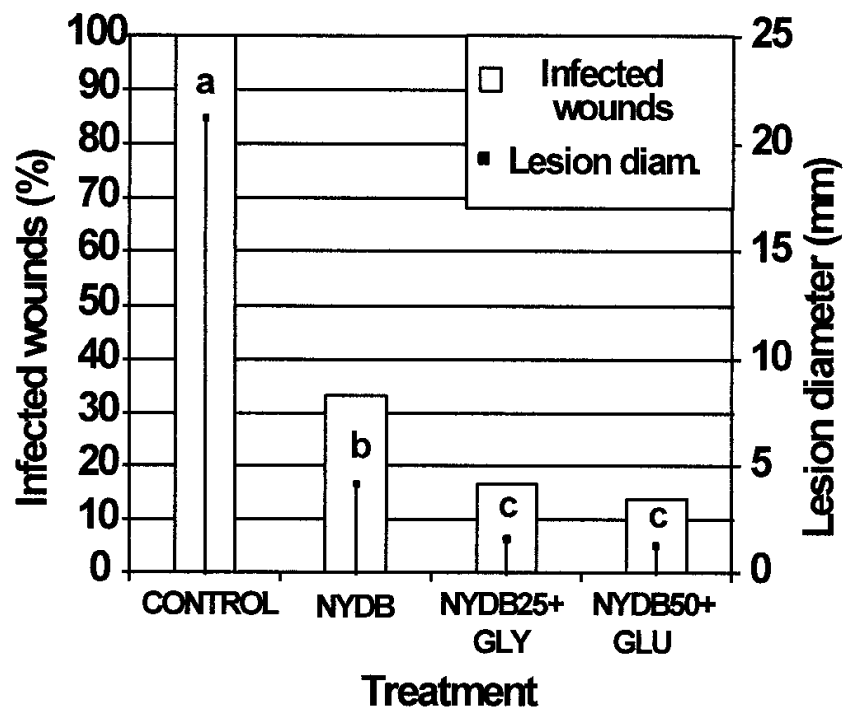

Fig. 4. Suppression of blue mold of 'Golden Delicious' apples by Candida sake CPA-1 grown in one unmodified and two different modified media. Fruits were wounded, treated with the three antagonist treatments, inoculated with Penicillium expansum at $10^{4}$ conidia per $\mathrm{ml}$, and incubated for 7 days at $25^{\circ} \mathrm{C}$. Columns and lines with the same letters are not significantly different $(P=0.0001)$ according to the least significant difference test. The letters apply to both percentage of infected wounds and lesion diameter. Treatments consisted of $C$. sake grown in unmodified nutrient yeast dextrose broth (NYDB), in NYDB diluted by $50 \%$ with water and amended with glucose to modify water activity $\left(a_{\mathrm{w}}\right)$ to 0.96 (NYDB50+GLU), and in NYDB diluted by $75 \%$ with water and amended with glycerol to modify $a_{\mathrm{w}}$ to 0.96 (NYDB25+GLY). 
the matrix. More knowledge may be needed to identify these subtle changes during the production of modified cells under water stress conditions.

We believe that there may be a number of advantages to preharvest application of biocontrol agents for postharvest control of pome fruit diseases, provided they are ecologically competent or the inoculum quality can be retained. This would result in less fruit manipulation and decrease the potential for damage and injuries that may occur during postharvest treatment. It would decrease the time periods between harvest and cold storage required for application of treatments and also avoid additional contamination by pathogenic fungi from drenching solutions usually used during chemical treatments.

\section{ACKNOWLEDGMENTS}

We thank the Spanish Government (CICYT Comisión Interministerial de Ciencia y Tecnología grant ALI96-0567) and the Catalonian Government (CIRIT Comissió Interdepartamental de Recerca i Tecnologia) for their financial support.

\section{LITERATURE CITED}

1. Beever, R. E., and Laracy, E. P. 1986. Osmotic adjustment in the filamentous fungus Aspergillus nidulans. J. Bacteriol. 168:1358-1365.

2. Bertrand, P. F., and Saulie-Carter, J. L. 1978. The occurrence of benomyltolerant strains of Penicillium expansum and Botrytis cinerea in midColumbia region of Oregon and Washington. Plant Dis. Rep. 62:305-320.

3. Biggs, A. R. 1995. Detection of latent infections in apple fruit with paraquat. Plant Dis. 79:1062-1067.

4. Brown, A. D. 1978. Compatible solutes and extreme water stress in eukaryotic microorganisms. Adv. Microbiol. Physiol. 17:181-242.

5. Deacon, J. W. 1991. Significance of ecology in the development of biocontrol agents against soil-borne plant pathogens. Biocontrol Sci. Technol. 1:5-20.

6. Dekker, J., and Georgopoulos, S. G. 1982. Fungicide Resistance in Crop Protection. Center of Agricultural Publishing and Documentation, Wageningen, the Netherlands.

7. Elad, Y. 1990. Reasons for the delay in development of biological control of foliar pathogens: Phytoparasitica 18:99-105.

8. Elad, Y., and Kirshner, B. 1992. Establishment of an active Trichoderma population in the phylloplane and its effect on grey mould (Botrytis cinerea). Phytoparasitica 20(Suppl.):137-141.

9. Elad, Y., and Kirshner, B. 1993. Survival in the phylloplane of an introduced biocontrol agent (Trichoderma harzianum) and populations of the plant pathogen Botrytis cinerea as modified by abiotic conditions. Phytoparasitica 21(4):303-313.

10. Ellis, S. W., Grindle, M., and Lewis, D. H. 1991. Effect of osmotic stress on yield and polyol content of dicarboximide-sensitive and -resistant strains of Neurospora crassa. Mycol. Res. 95:457-464.

11. Hallsworth, J. E., and Magan, N. 1994. Improved biological control by changing polyols/trehalose in conidia of entomopathogens. Proc. Br. Crop Prot. Conf. Pests Dis. 8D:1091-1096.

12. Hallsworth, J. E., and Magan, N. 1995. Manipulation of intracellular glycerol and erythritol enhances germination of conidia at low water availability. Microbiology-UK 141:1109-1115.

13. Harman, G. E., Jin, X., Stasz, T. E., Peruzotti, G., Leopold, A. C., and Taylor, A. G. 1991. Production of conidial biomass of Trichoderma harzianum for biological control. Biol. Control 1:23-28.

14. Hocking, A. D. 1986. Effects of water activity and culture age on the glycerol accumulation patterns of five fungi. J. Gen. Microbiol. 132:269-275.

15. Janisiewicz, W. J., and Bors, B. 1995. Development of microbial community of bacterial and yeast antagonists to control wound-invading postharvest pathogens of fruits. Appl. Environ. Microbiol. 61:3261-3267.

16. Janisiewicz, W. J., and Marchi, A. 1992. Control of storage rots on various pear cultivars with a saprophytic strain Pseudomonas syringae. Plant Dis. 76:555-560

17. Kelly, D. J., and Budd, K. 1991. Polyol metabolism and osmotic adjustment in the mycelial ascomycete Neucosmospora vasinfecta. Exp. Mycol. 15:55-64.

18. Koch, E. 1996. Mode of action and potential use of microbial antagonists of plant diseases. Gesunde Pflanz. 48:11-19.

19. Köhl, J., Molboek, W. M. L., van der Plas, C. H., and Fokkema, N. J. 1995. Effect of Ulocladium atrum and other antagonists on sporulation of Botrytis cinerea on dead lily leaves exposed to field conditions. Phytopathology 85:393-401

20. Köhl, J., van der Plas, C. H., Molhoek, W. M. L., and Fokkema, N. J.
1995. Effect of interrupted leaf wetness periods on suppression of sporulation of Botrytis allii and B. cinerea by antagonists on dead onion leaves. Eur. J. Plant Pathol. 101:627-637.

21. Leibinger, W., Breuker, B., Hahn, M., and Mengden, K. 1997. Control of postharvest pathogens and colonization of the apple surface by antagonistic microorganisms in the field. Phytopathology 87:1103-1110.

22. Louis, I. F. N., and Cooke, R. C. 1983. Influence of the conidial matrix of Sphaerellopsis filum (Darluca filum) on spore germination. Trans. Br. Mycol. Soc. 81:667-670.

23. Louis, I. F. N., and Cooke, R. C. 1985. Conidial matrix and spore germination in some plant pathogens. Trans. Br. Mycol. Soc. 84:661-667.

24. McKenzie, L. I., Benzi, D., Dellavalle, D., and Gullino, M. L. 1991. Survival on the phylloplane of strains of Trichoderma spp. antagonistic to Botrytis cinerea. Petria 1:133-134.

25. Norman, C. 1988. EPA sets new policy on pesticides risks. Science 242: 366-367.

26. Panek, A. 1963. Function of trehalose in baker's yeast (Saccharomyces cerevisiae). Arch. Biochem. Biophys. 100:422-425.

27. Parbery, I. H., Brown, V. J., and Bofinger, V. J. 1981. Statistical methods in the analysis of phylloplane populations. Pages 47-65 in: Microbial Ecology of the Phylloplane. J. P. Blakeman, ed. Academic Press. Inc., London.

28. Pascual, S., Magan, N., and Melgarejo, P. 1996. Improved biocontrol of peach twig blight by physiological manipulation of Epicoccum nigrum. Proc. Br. Crop Prot. Conf., Pests Dis. 4D:411-412.

29. Pusey, P. L., Hotchkiss, M. W., Dullmage, H. T., Baumgardner, R. A., Zehr, E., Reilly, C. C., and Wilson, C. L. 1988. Pilot tests for commercial production and application of Bacillus subtilis (B-3) for postharvest control of peach brown rot. Plant Dis. 72:622-626.

30. Pusey, P. L., and Wilson, C. L. 1984. Postharvest biological control of stone fruits brown rot by Bacillus subtilis. Plant Dis. 68:753-756.

31. Rendall-Dunn, A. J., ed. 1991. General News. Postharvest News and Information 2:3.

32. Roberts, R. G. 1994. Integrating biological control into postharvest disease management strategies. HortScience 29:758-762.

33. Rosenberger, D. A., and Meyer, F. W. 1979. Benomyl-tolerant Penicillium expansum in apple packinghouses in eastern New York. Plant Dis. Rep. 63:37-40.

34. Smilanick, J. L., and Denis-Arrue, R. 1992. Control of green mold of lemons with Pseudomonas species. Plant. Dis. 76:481-482.

35. Smilanick, J. L., Denis-Arrue, R., Bosch, J. R., Gonzalez, A. R., Henson, D., and Janisiewicz, W. J. 1993. Control of postharvest brown rot of nectarines and peaches by Pseudomonas species. Crop Prot. 12:513520.

36. Spotts, R. A., and Cervantes, L. A. 1986. Population pathogenicity and benomyl resistance of Botrytis spp., Penicillium spp. and Mucor piriformis in packinghouses. Plant Dis. 70:106-108.

37. Teixidó, N., Viñas, I., Usall, J., and Magan, N. Improving ecological fitness and environmental stress tolerance of the biocontrol yeast Candida sake by manipulation of intracellular sugar alcohol and sugar content. Mycol. Res. In press

38. Teixidó, N., Viñas, I., Usall, J., Sanchis, V., and Magan, N. 1998. Ecophysiological responses of the biocontrol yeast Candida sake CPA-1 to water temperature and pH stress. J. Appl. Microbiol. 84:192-200.

39. Usall, J. 1995. Control biologic de Penicillium expansum en postcollita de fruita de llavor. Universitat de Lleida, Spain.

40. Van Eck, J. H., Prior, B. A., and Brandt, E. V. 1993. The water relations of growth and polyhydroxy alcohol production by ascomycetous yeasts. J. Gen. Microbiol. 139:1047-1054.

41. Van Laere, A. 1989. Trehalose, reserve and/or stress metabolite? FEMS (Fed. Eur. Microbiol. Soc.) Microbiol. Rev. 63:201-210.

42. Viñas, I., Usall, J., and Sanchis, V. 1991. Tolerance of Penicillium expansum to postharvest fungicide treatment in apple packinghouses in Lleida (Spain). Mycopathologia 113:15-18.

43. Viñas, I., Usall, J., Teixidó, N., Fons, E., and Ochoa de Eribe, J. 1996. Successful biological control of the major postharvest diseases of apples and pears with a new strain of Candida sake. Proc. Br. Crop Prot. Conf. Pests Dis. 6C:603-608.

44. Viñas, I., Vallverdú, N., Monllao, S., Usall, J., and Sanchis, V. 1993. Imazalil resistant Penicillium isolated from Spanish apples packinghouses. Mycopathologia 123:27-33.

45. Wilson, C. L., and Chalutz, E. 1989. Postharvest biological control of Penicillium rots of citrus with antagonistic yeasts and bacteria. Sci. Hortic. (Amst.) 40:105-112.

46. Windels, C. E., and Lindow, S. E., eds. 1985. Biological Control on the Phylloplane. The American Phytopathological Society, St. Paul, MN.

47. Wisniewski, M. E., and Wilson, C. L. 1992. Biological control of postharvest diseases of fruits and vegetables: Recent advances. HortScience 27:94-98. 